This document was prepared in conjunction with work accomplished under Contract No. DE-AC09-96SR18500 with the U. S. Department of Energy.

\title{
DISCLAIMER
}

This report was prepared as an account of work sponsored by an agency of the United States Government. Neither the United States Government nor any agency thereof, nor any of their employees, nor any of their contractors, subcontractors or their employees, makes any warranty, express or implied, or assumes any legal liability or responsibility for the accuracy, completeness, or any third party's use or the results of such use of any information, apparatus, product, or process disclosed, or represents that its use would not infringe privately owned rights. Reference herein to any specific commercial product, process, or service by trade name, trademark, manufacturer, or otherwise, does not necessarily constitute or imply its endorsement, recommendation, or favoring by the United States Government or any agency thereof or its contractors or subcontractors. The views and opinions of authors expressed herein do not necessarily state or reflect those of the United States Government or any agency thereof. 


\section{SRAT/SME Vessel}

by

JAMES DOBOS

Westinghouse Savannah River Company

Savannah River Site

Aiken, South Carolina 29808

Additional Authors:

This paper was prepared in connection with work done under the above contract number with the U. S.

Department of Energy. By acceptance of this paper, the publisher and/or recipient acknowledges the U. S. Government's right to retain a nonexclusive, royalty-free license in and to any copyright covering this paper, along with the right to reproduce and to authorize others to reproduce all or part of the copyrighted paper. 


\section{Savannah River National Laboratory \\ Analytical Development \\ J.G. Dobos}

\section{Background}

The Defense Waste Processing Facility (DWPF), at the Savannah River Site (SRS), is processing and immobilizing the radioactive high level waste sludge slurry at SRS into a durable borosilicate glass for final geological disposal. Each time a new batch of radioactive sludge is to be processed by the DWPF, the process flow sheet is to be tested and demonstrated to ensure an acceptable melter feed and glass can be made. These demonstrations are completed in the Shielded Cells Facility in the Savannah River National Laboratory at SRS.

\section{System Description}

One of the first generation SRAT/SME vessels used for the DWPF melter feed qualification testing consisted of a one piece vessel made from $100 \mathrm{~mm}$ medium wall tubing. The vessel's top was composed of: two \#7 threads, one \#11, two 24/40's, one 7/25 and one 14/20. The total height measured approximately 8 inches and held approximately 1-liter.

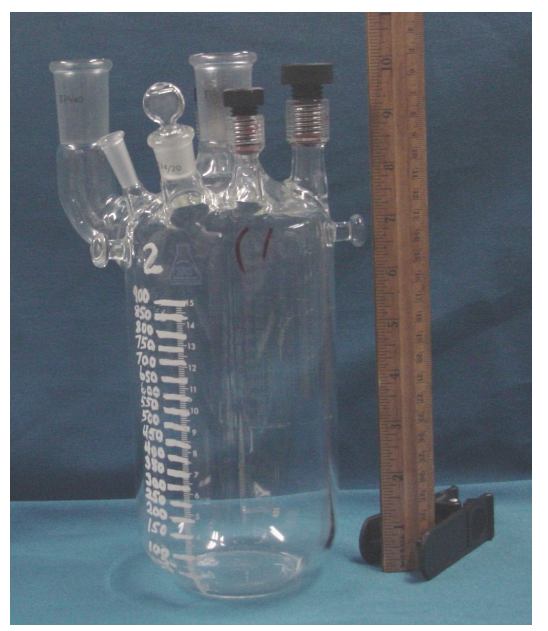

The second generation SRAT/SME vessel design used for testing consists of a glass reaction vessel approximately 13 inches $(33 \mathrm{~cm})$ in height and 6 inches $(15 \mathrm{~cm})$ diameter. The SRAT/SME vessel has a capacity of approximately 2 liters and a series of ports and openings, similar to the one-piece unit. These ports and openings are for the installation of equipment (i.e. pH probe, thermocouple, agitator, etc.) and process lines (acid addition, air purge, etc.). The condenser, mercury/condensate trap, and cold trap connected to the SRAT/SME vessel are also made out of glass.

To supply heat to the SRAT/SME vessel, a cylindrical heating mantle is used. Also, a laboratory chiller unit is used to supply the chilled water for the condenser. Figure 2 is a picture taken in the Mockup Cells of the system prior to installation in the Shielded Cells. 
Picture of the SRAT/SME Vessel in the Mockup Cells of the Shielded Cells Facility (Figure 2)

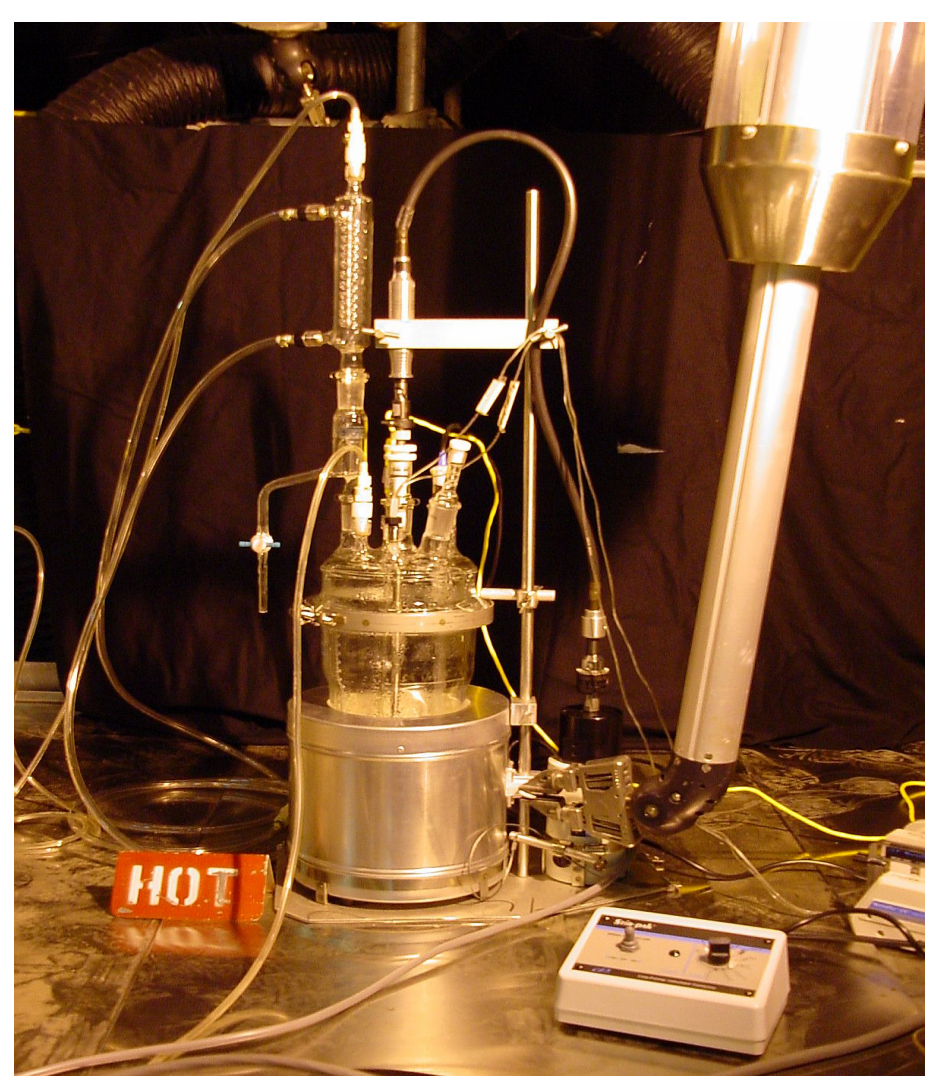

\section{Information on the DWPF SRAT and SME CYCLES}

Producing an acceptable melter feed from radioactive sludge slurry is demonstrated by performing two separate DWPF processing cycles. The first cycle is the Sludge Receipt and Adjustment Tank (SRAT) cycle and the second cycle is the Slurry Mix Evaporator (SME) cycle. Approximately 1-liter of radioactive sludge is used to demonstrate both the SRAT and SME cycles.

The first step of the SRAT cycle is to heat the sludge to $93^{\circ} \mathrm{C}$. After reaching this temperature, nitric and formic acids are added to the sludge slurry to react with carbonates and hydroxides in the sludge to adjust its rheology and to reduce $\mathrm{Hg}$ ions in the sludge. At the completion of the acid additions, the sludge is heated to boiling to steam strip mercury and remove water by obtaining the proper weight percent solids. During this cycle, the $\mathrm{pH}$ is monitored and a $5 \%$ $\mathrm{He} /$ air mixture continuously purged the SRAT/SME vessel to measure offgas composition. The offgas exiting the vessel is monitored by a gas chromatograph for $\mathrm{H}_{2}, \mathrm{He}, \mathrm{CO}_{2}$, and $\mathrm{N}_{2} \mathrm{O}$. The product of this cycle is then analyzed for chemical composition, weight percent solids and density as a precursor for starting the SME cycle.

Prior to the start of the SME cycle, the chemical compositions of acidified sludge and glass forming frit are entered into the DWPF process control program. This program contains algorithms that predicted certain properties that the melt and final product must meet in order to make a durable glass that can be processed through a melter. The program prescribes the proper amount of frit to be added and predicts the composition of the final product. 
After the calculations demonstrate that the product meets the acceptable properties, the acidified sludge is heated to $90^{\circ} \mathrm{C}$ to start the SME cycle. Upon reaching $90^{\circ} \mathrm{C}$, the prescribed amount of glass forming frit is added as a dry powder to the acidified sludge. Dilute formic acid water additions followed the frit addition to simulate the frit slurry addition method in the DWPF. After the additions are complete, the acidified sludge/frit mixture is heated to $100^{\circ} \mathrm{C}$ to remove water to obtain the correct weight percent solids. The SRAT/SME vessel is also continuously purged during this cycle by a $5 \% \mathrm{He} / \mathrm{air}$ mixture. The offgas exiting the vessel is monitored by the gas chromatograph for $\mathrm{H}_{2}, \mathrm{He}, \mathrm{CO}_{2}$, and $\mathrm{N}_{2} \mathrm{O}$.

\section{Need for Mini-SRAT Reaction Vessel for Rheology Studies}

The Glass Development Lab (GDL) was asked to design and manufacture four, MiniSRAT vessels to be used for rheolgy studies, similar to the 2-liter vessels. One of the concerns associated with the vessel's design was the small volume of sample that was offered for testing. The customer requested the vessel to hold approximately 250 to $300 \mathrm{ml}$, with a workable mixing volume of $150 \mathrm{ml}$ and measuring no taller than 3.5 to 4 inches. This was considerable smaller than the original SRAT which measured 13 inches tall and approximately 6 inches wide with a capacity of 2-liters. The slurry was to be heated using a controlled heating source and all instrumentation that was used on the larger SRAT vessel were to be incorporated into the new design.

The bottom section of the Mini-SRAT was made using glass tubing measuring $57 \mathrm{~mm}$ in diameter. This would allow the use of a standard heating mantle, normally used for heating beakers with the same diameter. A standard minitrol was used to control the temperature of the vessel. A $100 \mathrm{~mm}$ Duran flat ground, o-ring grooved flange was used to mate with the top section, similar in every detail except for its physical size. By designing the vessel to use a standard heating mantle, time and money was not wasted on design and special ordering a mantle for the unique vessel. The vessel top was made using the same orientation as with the larger vessel, with a few modifications. The alignment and placement of the connectors were even more critical, due to the limited space on the vessel top. Special off-set adapters were made to accommodate the installation of equipment as before (i.e. condenser, $\mathrm{pH}$ probe, stirrer, thermocouple, pressure relief valve, process lines, acid addition, air purge, etc.).

Picture of the SRAT/SME Vessel and Modified Mini-SRAT (Figure3 \& 4)
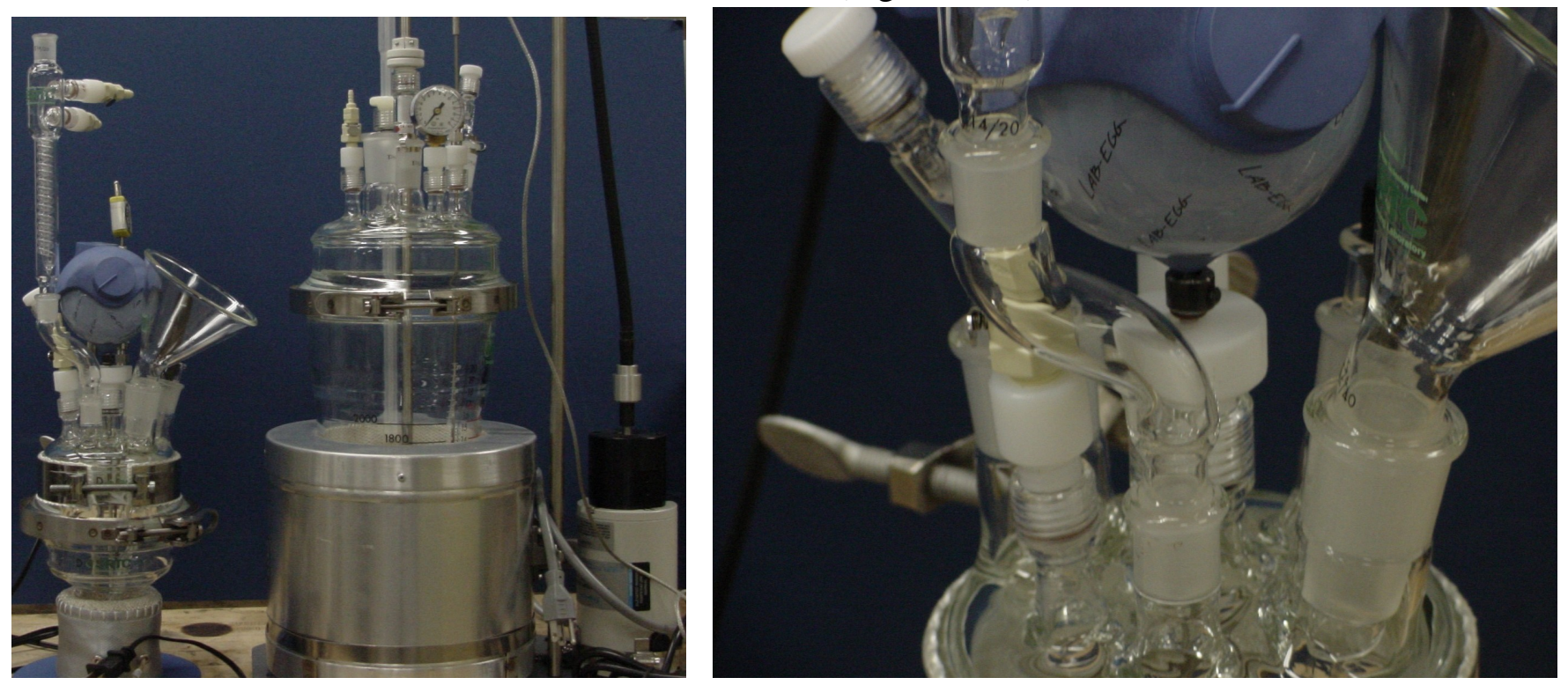
The latest changes to the vessel has been to redesign the condenser and mercury water wash tank to more closely represent what is currently being used in the plant. The modified condenser pictured in figure 5, is used on a 22-liter set-up, with figure 7 showing holder used to make apparatus. Figure 6 is a micro version used on the 2-liter vessel.
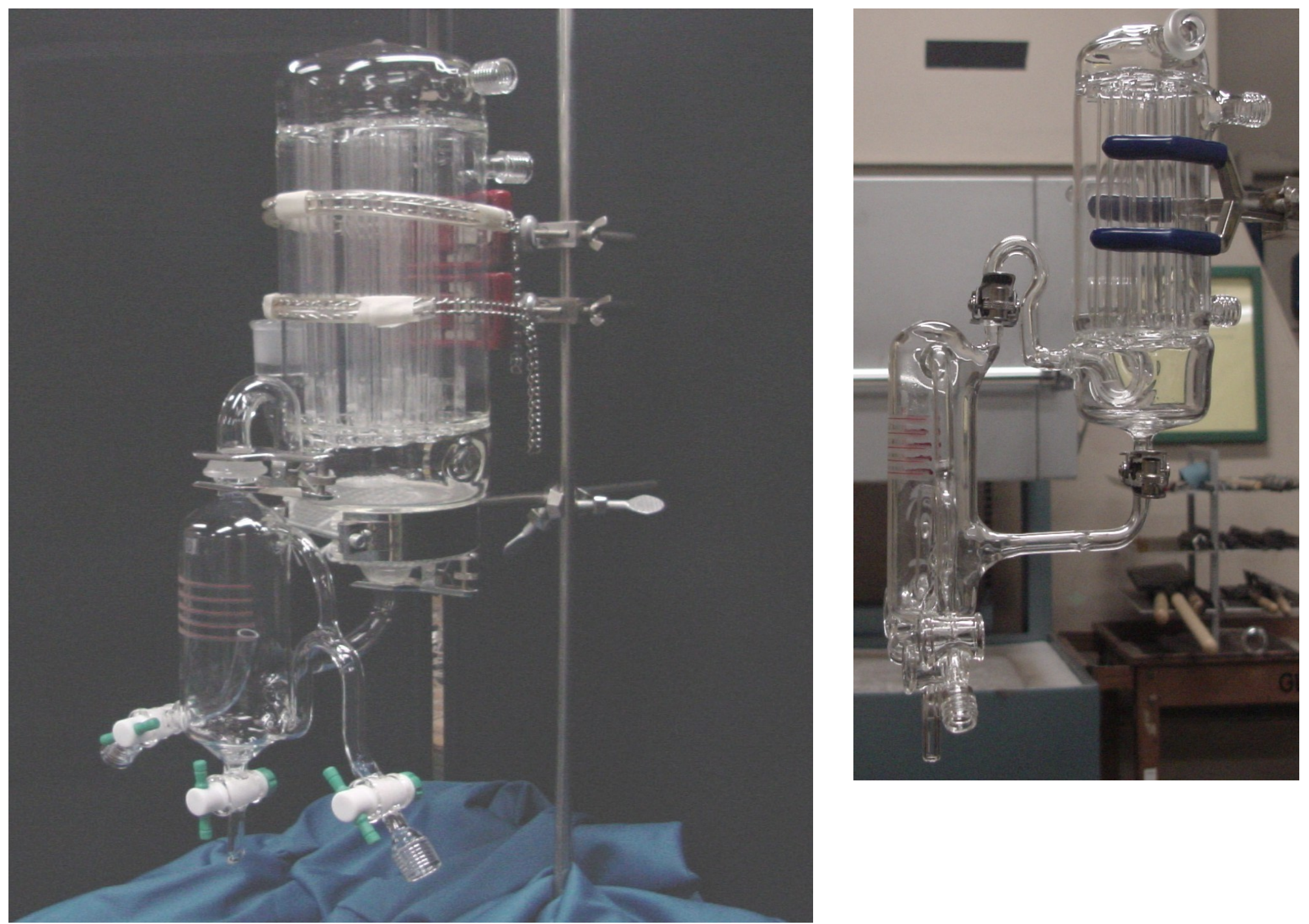

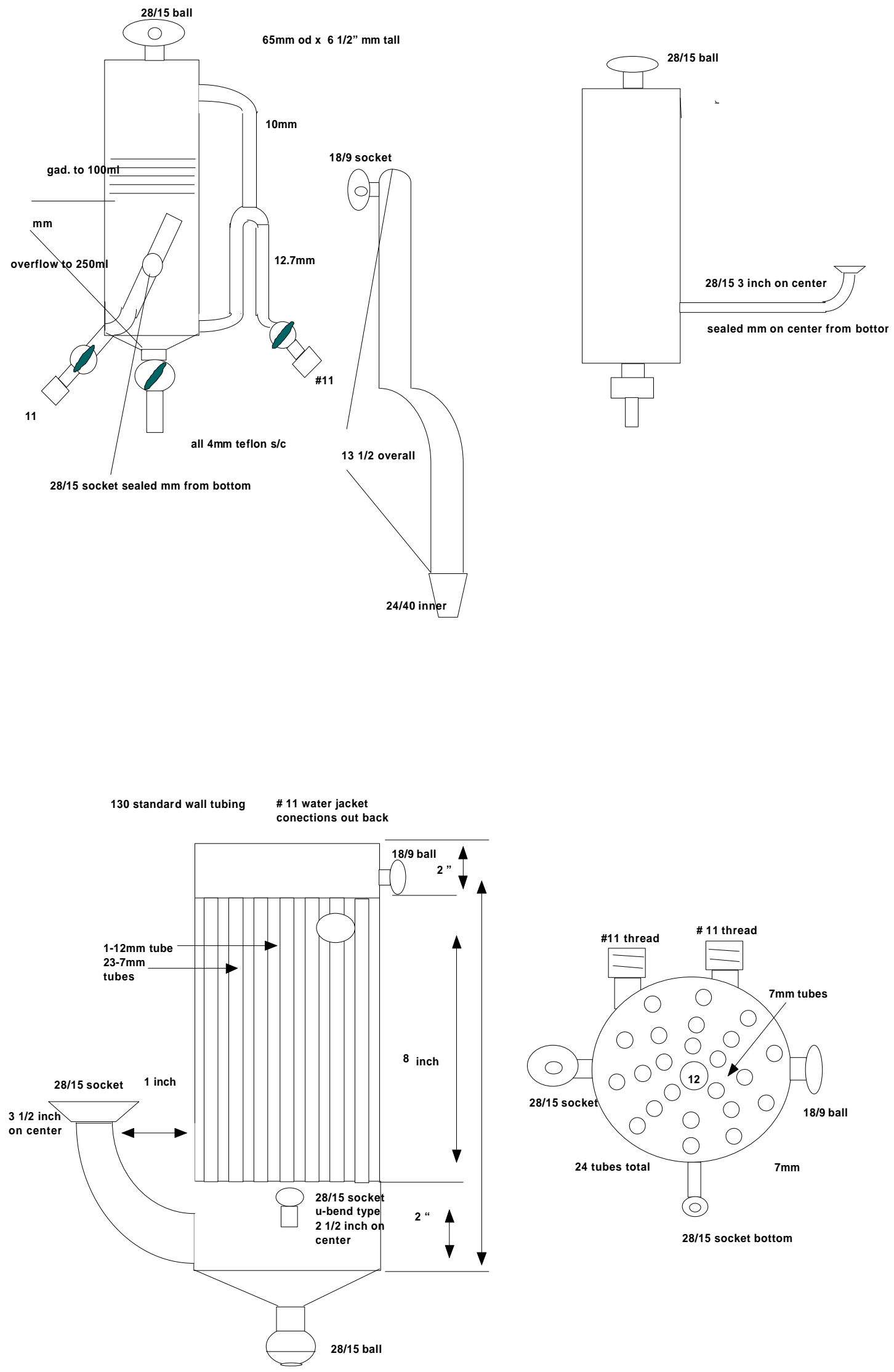

28/15 socket bottom 
Figure 7

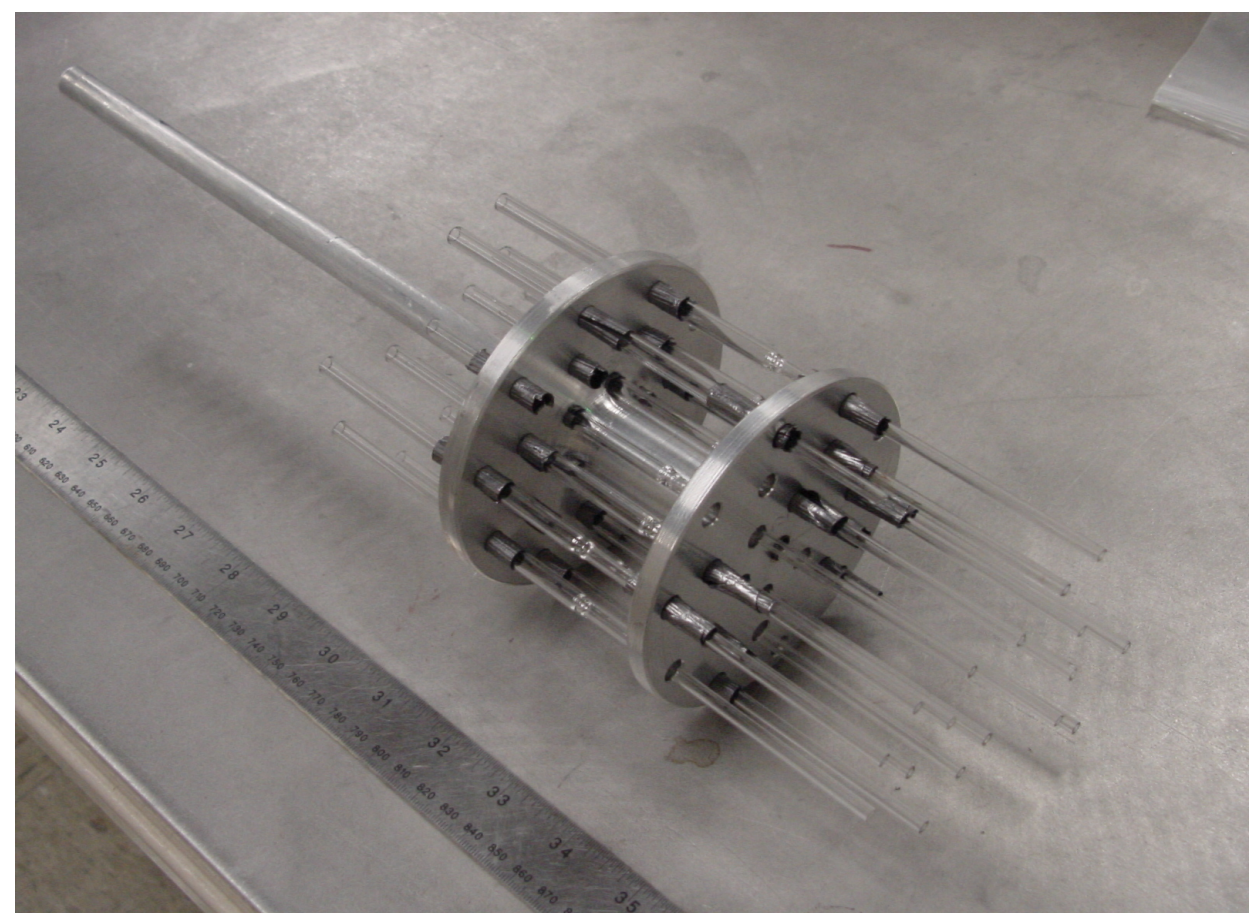

\section{Summary}

The design of the SRAT vessels by the GDL and testing preformed by the SRNL Shielded Cells had a positive impact on the feed qualifications and scheduling of the immobilizing of high level waste sludge slurry. The quick design of the vessels enabled fast turn-around of results needed to satisfy concerns at the Defense Waste Processing Facility. These studies were important to maintain the current schedule which is directly associated hard dollars and bonus awards for filling of canisters that meet or exceed the Department of Energy expectations. 